8. Uil'son, Je. (2011). Mstislav Rostropovich: teacher, legend. Moskva: Jesmo [in Russian].

9. Hentova, S. (1993). Rostropovich. Sankt-Peterburg: Kul't-informpress [in Russian].

10. Jampol'skij, I. (1974). Daniel Shafran. Moskva: Sovetskij kompozitor [in Russian].

UDC 78.08; 78.2

DOI $10.33287 / 221913$

\begin{abstract}
Shchitova Svitlana Ph.D., Associate Professor, Head of ,History and Theory of Music” chair of M. Glinka Dnipropetrovsk Academy of music тел. (093) 151 - 99 - 81 e-mail: shchitova@i.ua
\end{abstract}

Yakimets Alexander Master of ,Academic singing” chair of M. Glinka Dnipropetrovsk Academy of music тел. (066) 625 - 56 - 58 e-mail: Yakimets1754@ukr.net

\title{
THE INNOVATIVE INTERPRETATION OF THE CHAMBER-VOCAL GENRE IN THE LATE WORKS OF SCHUBERT
}

The purpose of the study is to prove the innovative approaches of F. Schubert in vocal works on the example of his later opuses - the vocal cycle „Winterreise”, op. 90 (,Winter Road”) and the song collection „Der Schwanengesang” (,Swan Song”). The methods of this proposed scientific article are based on the research approaches (historical, compare, analytical), which allow to us to follow the path of dramatization of the song in the late works of F. Schubert, as well as to determine the conformity of the vocal intonation to the poetic text. The material of scientific intelligence there are ten separate songs, namely, five songs from the vocal cycle ,Winter Path" and five songs on the lyrics by G. Heine from the collection ,Swan Song”. In our opinion, they are not only indicative, but also similar in form, methods and content. The scientific 
novelty of this research is to in the treatment to the issues of determining the correspondence of vocal intonation to a poetic text. Conclusions. Lyrics by Wilhelm Muller and Heinrich Heine are the peak of Schubert's vocal lyrics, the starting point for the further development of the song (romance) genre. Simplicity and the associated „sociability" of song intonation, on the one hand, naturally continue the traditions of the AustroGerman song Lied. However, while the melody of Schubert reveals time fundamentally new qualities caused by the composer's innovative attitude to its formation. The reason for this is a great attention to the verbal text. The close interaction of poetic words and music, especially in the late works of the composer romantic, gives rise to a fundamentally new type of vocal intonation, a new level of voice and accompaniment and, as a final result, the emergence of a new quality of the chamber-vocal work „poems with music", thereby pushing on the further path of development of chamber vocal genres.

The key words: melody, poetry, romantic, cycle, complitation, creativity, intonation.

Щітова Світлана Анатоліївна, кандидат мистецтвознавства, доцент, завідувач кафедри „Історія та теорія музики” Дніпропетровської академії музики ім. М. Глінки

Якимець Олександр Миколайович, магістрант кафедри „Академічний спів” Дніпропетровської академії музики ім. М. Глінки

Новаторська трактовка камерно-вокальних жанрів у пізній творчості Ф. Шуберта

Мета дослідження - довести новаторські підходи Ф. Шуберта до вокальних творів на прикладі його пізніх опусів - вокального циклу „Winterreise”, op. 90 (,Зимовий шлях”) та пісенної збірки „Der Schwanengesang” („Лебедина пісня”). Методи пропонованої наукової статті грунтуються на дослідницьких підходах (історичний, порівняльний, аналітичний), які дозволяють простежити шлях драматизації пісні у пізній творчості Ф. Шуберта, а також визначити відповідність вокальної інтонації поетичному тексту. Матеріалом наукової розвідки постають десять окремих пісень, а саме п'ять пісень 3 вокального циклу „Зимовий шлях” та п’ять пісень на сл. Г. Гейне зі збірки „Лебедина пісня”. На нашу думку, вони постають не тільки показовими, а ще й схожими за формою, прийомами i змістом. Наукова новизна зазначеної теми полягає у зверненні до питань визначення відповідності вокальної інтонації поетичному 
тексту. Висновки. Пісні на слова Вільгельма Мюллера й Генріха Гейне - вершина шубертівської вокальної лірики, вихідна точка подальшого розвитку пісенного (романсового) жанру. Простота i пов'язана 3 нею „товариськість” пісенної інтонації, з одного боку, закономірно продовжують традиції австро-німецької пісні Lied. Однак, при цьому, мелодика Шуберта виявляє часом принципово нові якості, викликані новаторським ставленням композитора до іiі формування. Причиною тому служить велика увага до словесного тексту. Тісна взаємодія поетичного слова і музики, особливо у пізній творчості композитора-романтика, народжує принципово новий тип вокальної інтонації, нового рівня співвідношення голосу і супроводу та, як кінцевий результат - зародження нової якості камерновокального твору - „вірші з музикою”, тим самим підштовхуючи на подальший шлях розвитку камерно-вокальні жанри.

Ключові слова: мелодія, поетичність, романтик, цикл, збірка, творчість, інтонація.

Щитова Светлана Анатольевна, кандидат искусствоведения, доцент, заведующая кафедрой „История и теория музыки” Днепропетровской академии музыки им. М. Глинки

Якимец Александр Николаевич, магистрант кафедры „Академическое пение” Днепропетровской академии музыки им. М. Глинки

Новаторская трактовка камерно-вокальных жанров в позднем творчестве Ф. Шуберта

Цель исследования - доказать новаторские подходы Ф. Шуберта в вокальных произведениях на примере его поздних опусов - вокального цикла „Winterreise”, op. 90 (,Зимний путь”) и песенного сборника „Der Schwanengesang” („Лебединая песня”). Методы научной статьи основываются на исследовательских подходах (исторический, сравнительный, аналитический), которые позволяют проследить путь драматизации песни в позднем творчестве Ф. Шуберта и определить соответствие вокальной интонации поэтическому тексту. Материалом научной работы стали десять отдельных песен, а именно пять песен из вокального цикла „Зимний путь” и пять песен на сл. Г. Гейне из сборника „Лебединая песня". По нашему мнению, они являются не только показательными, но и схожими по форме, приёмам и содержанию. Научная новизна данной темы заключается в обращении к вопросам соответствия 
вокальной интонации поэтическому тексту. Выводы. Песни на слова Вильгельма Мюллера и Генриха Гейне - вершина шубертовской вокальной лирики, исходная точка дальнейшего развития песенного (романсового) жанра. Простота и связанная с ней „общительность” песенной интонации, с одной стороны, закономерно продолжают традиции австро-немецкой песни Lied. Однако, при этом, мелодика Шуберта обнаруживает принципиально новые качества. Причиной тому служит большое внимание к словесному тексту. Тесное взаимодействие поэтического слова и музыки, особенно в позднем творчестве композитора-романтика, рождает принципиально новый тип вокальной интонации, новый уровень соотношения голоса и сопровождения и, как конечный результат, приводит к зарождению нового типа камерно-вокального произведения - „стихи с музыкой”, тем самым подталкивая на дальнейший путь развития камерновокальные жанры.

Ключевые слова: мелодия, поэтичность, романтик, цикл, сборник, творчество, интонация.

Problem statement of the research. Even during the composer's life, namely the song brought him fame, glory, recognition. The huge demand for the song heritage of the Austrian romantic remains in the present. Schubert's music is increasingly included in the concert repertoire, which is facilitated by the activities of Schubert societies in different countries of the world. It is natural to consider the interest of researchers to learn, the analysis of exactly song samples, or, in general, the song principles of the composer-romantic's thinking in works of various genres. From large number of songs written, special attention should be paid to the works of the $1820 \mathrm{~s}$, that is, the late period of Schubert. They personify the fundamentally new interpretation of chamber-vocal lyrics at all levels - the ratio of poetic and musical text, and the „dialogue" of the soloist and accompaniment, and the principles of shaping, and the birth of a new type of vocal intonation.

The relevance of research. The song genre, raised to the same level with other musical genres, is developed, updated, enriched in the late period of Schubert, namely in the vocal cycle „Winter Way”, the song collection ,Swan Song”.

Analysis of the literature. The work of Franz Schubert is studied in a sufficient amount of literature, but most of it is directed not at studying and analyzing the work of the composer, but more at examining his 
biographical information. In this context, we note the value of the collection „Music of Austria and Germany of the 20th century”, which synthesizes both monographic and analytical principles [1]. One of the outstanding „schubertovidiv" is Yu. M. Khokhlov. His works include monographs $[2,3]$, analytical studies, examining, among other things, the vocal cycles of Franz Schubert [4]. An important basis for studying the vocal music of Franz Schubert is the book „German poetry of the twentieth century", translated from German [5]. Interest in the study of the creative potential of F. Schubert in its various aspects continues in theses, devoted to the analysis of the author's categories in the chamber-vocal works of Schubert [6] the question of figurative and meaningful interpretation in the songs of Schubert [7].

The purpose of this scientific article is to prove the innovative approaches of F. Schubert in vocal works on the example of his later opuses.

The object of the research is F. Schubert's chamber-vocal lyrics as the main paradigm of his work, and the subject is F. Schubert's late song creativity, which gives grounds for the manifestation of new approaches to chamber-vocal works.

Statement of the base material. Franz Schubert is the first great composer, in whose work the border of the classical and romantic era is clearly defined. Poetic love and pure joy of life, despair and cold of loneliness, thirst for travel and hopelessness of wanderings inherent in a romantic worldview - all these found the feeling in the works of Schubert. Emotional openness, spontaneity of expression raised the genre of AustroGerman song to a high level, is widely represented in the ereations of romance. Khokhlov Yu.M. writes: „Schubert's music brought with it a new content, which corresponded to a new era" $[5,6]$.

Schubert's unsurpassed melodic gift made it possible to create several songs a day, so in a relatively short life the composer wrote over 600 samples of this genre.

If one can say about Bach that he thought polyphonically, Beethoven - symphonic, then Schubert reasoned ,song”. The melody as a type of thinking is present in his works of various genres, causing a special type of melody, texture, structure. Images and expressive means borrowed from vocal lyrics, as if reflected in almost all musical genres of F. Schubert, including the opera.

Even during the composer's lifetime, it was the song that brought him glory, fame, recognition. The huge demand for the song heritage of 
the Austrian romance remains in the present. Schubert's music is increasingly included in the concert repertoire, which is facilitated by the activities of Schubert societies in different countries of the world.

The song, raised to the same level with other musical genres, is fundamentally updated, enriched primarily in the late period of Schubert in his vocal cycle „Winterreise” („Winter Way”, 1827) and the song collection „Der Schwanengesang” (,Swan song”, 1828). The specified chamber-vocal works form new principles, new types vocal intonation, and in close connection with the poetic word constitute a new perspective of personal musical and poetic confession. Therefore, it can be argued that Schubert's late songs creations provide a basis for the manifestation of new approaches to the understanding of chamber and vocal works.

The content, orientation to the folk-song traditions of the AustroGerman Lied, the democratic poetry of V. Muller was especially close to the creative nature of Schubert, and their joint songs and „The Beautiful Mill” and the „Winter Path" „reflected the democratic tendencies of romantic individualism" $[3,23]$.

„Winter Way" is a unique vocal cycle, which organically combines intimate lyrical and sociopolitical themes, and by the level of philosophical aesthetics can replace an entire book. Numerous arrangements, theatrical performances and references to this cycle in various art forms confirm its significance and topicality. This is John Neumayer's ballet of the same name in the orchestral version of Hans Zehnder, in 2001, the film by Sergey Taramayev and Lyubov Lvova, 2013. The Winter Path cycle is a through line of the story in the film „The Pianist” by Michael Haneke based on the eponymous novel by Jelinek. In 2014, Schubert's cycle is presented in stage design, staged by William Kentridge and set design by Sabina Toinissen. The poet of the Silver Age, Mikhail Kuzmin, referred to the Schubert's creation in his last poem.

There is no development of plot in „The Winter Way”, and the songs are united by the tragic theme of the cycle, the moods by which they are determined. Franz Schubert succeeds in drawing techniques only in order to emphasize the drama of contrasts, such as dream and waking, memories and reality in the songs Spring Sleep and Lipa; or in order to provide a specific image of a symbolic meaning (,Crow”); the illustrative nature of the song „Mail” in this perspective is rather the exception.

The more complex (in equalized with the early vocal cycle) character of poetic images affected in the peaked drama of music with a predominance of a minor mode, with an emphasis on the inner, 
psychological side of life. It explains the significant complication of the musical language, the desire for dramatization of the form. Simple song forms are dynamized; a noticeable advantage of various types of three-part construction - with a developed middle part, with a dynamic reprise, variational changes in each part. We note that from 24 songs of the cycle only in two no repetitions of the poetic text are used and the musical form completely corresponds to the structure of the verse.

The singing melody of the cycle songs is enriched with declamatory and recitative turns, harmony with bold juxtapositions. From fourteen „Swan Song” six are written to the verses of Heinrich Heine, the poet who has a special place in German literature. Heine imposed new elements to the romantic lyrics - expansion of the thematic range with a new interpretation of the traditional for romantics themes, independent artistic style. In the form of folk poetry, Heine placed the complex spiritual world of modern art, pulling the significance of a realistic direction.

The form and the philosophical content of the song to poems of Heine are very similar to Schubert's songs from the „Winter Path" series to the words of Muller. They are an absolute reproduction of high, poetic texts, consoning with the composer's in-depth approach to the content of the vocal work.

The closeness of the spirit of the poetry of Muller and Heine is obvious. Even Heinrich Heine considered Wilhelm Muller to be his closest poet. Much in the creation of G. Heine was close to the composer:

- manifestation of the lyrics of the „myself”, taken in reserve of love experiences;

- an organic connection with a folk song;

- deep perspective, which opens with the images of the poet.

Conclusions. Songs to the words of Wilhelm Muller and Heinrich Heine are the pinnacle of Schubert's vocal lyricism, the starting point for the further development of the song (or romance) genre. Simplicity and the associated ,sociability" of song intonation, on the one hand, naturally continue the traditions of the Austro-German song Lied. However, while the melody of Schubert reveals time fundamentally new qualities caused by the composer's innovative attitude to its formation. The reason for this is a lot of attention to the verbal text. Cramped The interaction of poetic words and music, especially in the late works of the romantic composer, gives rise to a fundamentally new type of vocal intonation, a new level of voice and accompaniment ratio and, as a final result, the emergence of a 
new quality of the chamber-vocal work - ,poems with music”, thereby pushing on the further path of development of chamber vocal genres.

Franz Schubert in the song cycle „Winter Path" and in the songs from the collection „Swan Song” does not refuse the typical „small vocal forms". Depending on the artistic image, the correlation with the poetic text, the composer refers to: couplet-variation form (,Her portrait"); simple two-part form („Mail”); free couplet form („Travel pillar”); simple three-part form (,Spring dream”); stanzaic form (,Weathervane”). In his later vocal works, Schubert practically abandons the simple couplet form (the exception is „Fishing” from the „Swan Song”), to which he tended in early songs.

Outlook for further researches. The results of the study can be used in classes with solo and chamber singing, in class on the theory of music, musical literature. Prospects for further deepening into the stated problems can be directed to the vocal style of F. Schubert's operas of the 1820s „Fierrabras”, „Alfonso and Estrella”.

\section{Список використаних джерел і літератури:}

1. Немецкая поэзия XIX века: сборник на нем. и русск. яз. - сост. А.С. Дмитриев. Москва: Радуга, 1984. 704 с.

2. Хохлов Ю. Воспоминания о Шуберте. Москва: Музыка, 1964. 411 с.

3. Хохлов Ю. „Зимний путь” Франца Шуберта. Москва: Музыка, 1967. 65 с.

4. Хохлов Ю. О последнем периоде творчества Ф. Шуберта. Москва: Музыка, 1968. $64 \mathrm{c}$.

5. Хохлов Ю. Песни Ф. Шуберта: черты стиля. Москва: Музыка, 1987. 300 с.

6. Богомолов С.М. Песни Франца Шуберта как высокий жанр: дис. ... канд. искусствоведения: 17.00.02 „Музыкальное искусство”. Санкт-Петербург, 2000. $150 \mathrm{c}$.

7. Пилипенко Н.В. Слово и музыка в песнях Франца Шуберта: опыт образносмысловой интерпретации: дис. ‥ канд. искусствоведения: 17.00 .02 „Музыкальное искусство”. Москва, 2002. 330 с.

\section{References:}

1. German poetry of the XIX century, (1984). Moskva: Raduga [in Russian].

2. Hohlov, Ju. (1964). Memories of Schubert. Moskva: Muzyka [in Russian].

3. Hohlov, Ju. (1967). „Winter Way” by Franz Schubert. Moskva: Muzyka [in Russian]. 
4. Hohlov, Ju. (1968). About the last period of the work of F. Schubert. Moskva: Muzyka [in Russian].

5. Hohlov, Ju. (1987). Songs F. Schubert: style features. Moskva: Muzyka [in Russian].

6. Bogomolov, S.M. (2000). Songs of Franz Schubert as a high genre. Candidate dissertation. Sankt-Peterburg [in Russian].

7. Pilipenko, N.V. (2002). Word and music in the songs of Franz Schubert: the experience of figurative and semantic interpretation. Candidate dissertation. Moskva [in Russian].

UDC 78.082

DOI $10.33287 / 221914$

Тарасова Наталія Юріївна, кандидат філософських наук, доиент кафедри „, Історія та теорія музики” Дніпропетровської академії музики ім. М. Глінки тел. (095) 315 - 35 - 77 e-mail: tarasova116@ukr.net

Москальов Богдан Ігорович, магістрант кафедри „Оркестрові інструменти” Дніпропетровської академії музики ім. М. Глінки тел. (063) 704 - 27 - 15 e-mail:mr.psyker@gmail.com

\section{МОВА ДЖАЗУ В ІНСТРУМЕНТАЛЬНІЙ СЮЇТІ ХХ ст. (на матеріалі сюїти для фортепіано ,1922” П. Гіндеміта і „Сюїти настроїв” Ю. Чугунова)}

Мета статті - виявити індивідуальні композиторські засоби синтезу джазової стилістики із засобами виразності музики XX століття у жанровому контексті сюїти. Методи дослідження спираються на застосування музично-культурологічного, порівняльно-історичного, теоретико-аналітичного, текстологічного підходів. Наукова новизна. Вперше здійснюється компаративний аналіз сюїти для фортепіано „1922” Пауля Гіндеміта та „Сюїти настроїв” Юрія Чугунова 1) з точки зору жанрових оновлень сюїти елементами джазової стилістики та джазовими виконавськими 